\title{
Effect of Proposed Large Dams on Water Flows and Hydropower Production in the Sekong, Sesan and Srepok Rivers of the Mekong Basin
}

\author{
Thanapon Piman ${ }^{1,2}$, Thomas A. Cochrane ${ }^{1 *}$, and Mauricio E. Arias ${ }^{1,3}$ \\ ${ }^{1}$ Department of Civil and Natural Resources Engineering, University of Canterbury, \\ Christchurch, New Zealand. \\ ${ }^{2}$ Currently at Mekong River Commission, Climate Change and Adaptation Programme, \\ Vientiane, Lao PDR \\ ${ }^{3}$ Currently at Sustainability Science Program, Harvard University, Cambridge, USA \\ ${ }^{*}$ Corresponding author: tom.cochrane@canterbury.ac.nz
}

\begin{abstract}
Water flow patterns in the Mekong are changing due to on-going rapid hydropower development triggered by economic growth. Of immediate concern are the current and proposed hydropower dams in the transboundary Srepok, Sesan and Srekong (3S) Rivers, which contribute up to $20 \%$ of the Mekong's annual flows, have a large potential for energy production, and provide critical ecosystem services to the downstream Tonle Sap Lake and Mekong Delta. The objective of this paper is to determine how the operation of the proposed largest individual dams and cascade dams schemes in the 3S Rivers will affect flow regimes and energy production. Daily flows were simulated over 20 years using the SWAT and HECResSim models for a range of dam development and operations scenarios. The development of all dams in the $3 \mathrm{~S}$ basin under an operation scheme to maximize individual electricity production results in an average $98 \%$ increase in dry season flows at the $3 \mathrm{~S}$ outlet. Over 55\% of dry season flows changes are caused by seven proposed large dams, with the Lower Srepok 3 project causing the highest impact. The seven large dams will generate $33.0 \mathrm{GWh}$ /day with a water volume of 17,679 million $\mathrm{m}^{3}$, compared to the current and definite future dams generating $73.2 \mathrm{GWh} /$ day with a much lower volume of 6,616 million $\mathrm{m}^{3}$. When a cascade of dams are operational, downstream dams with small reservoirs will produce more energy. However, the marginal increase in energy production from the development of additional dams in the $3 \mathrm{~S}$ basin will decline rapidly relative to the required water storage increase,. Strategic decision making on the future of each large proposed dam in the $3 \mathrm{~S}$ basin needs to be considered by local governments after understanding cumulative operation effects and with further consideration to the potential impact on downstream ecosystem productivity and livelihoods.
\end{abstract}

Keywords: Southeast Asia; HEC-ResSim; hydrological modelling, dam operation; hydropower; Mekong

\section{Introduction}

The Mekong River flows 4,800 km from Tibet through China, Myanmar, Lao PDR, Thailand, Cambodia, the Vietnam Delta, and into the South China Sea, draining an area of 795,000 km². The Upper Mekong Basin encompasses parts of China and Myanmar (the river in China is also known as the Lancang River) and the Lower Mekong Basin includes parts of Lao PDR, 
Thailand, Cambodia, and Viet Nam. The division of the basin into two parts is a logical expression of physical, climatic and hydrological and administrative differences (Carling, 2009). The upper part is narrow and topographically steep with no significantly large tributary systems. The lower part is wide with very large tributary river systems. In 1995, Lao PDR, Thailand, Cambodia and Vietnam signed the Mekong Agreement and established the Mekong River Commission (MRC) to assist member countries in sustainable management and development of water and related resources in the Lower Mekong Basin. China and Myanmar were engaged as MRC Dialogue Partners in 1996 to enhance cooperation for the whole basin.

Flows in the Mekong are naturally controlled by the East Asian monsoons, resulting in an annual unimodal flood pulse (Adamson et al., 2009; Delgado et al., 2012, 2010). The Mekong's mean annual flow is about $460 \mathrm{~km}^{3}$ and it ranks $10^{\text {th }}$ among the world largest rivers (Dai and Trenberth, 2002). About $75 \%$ of the annual flow in an average year occurs in the four months between July and October (MRC, 2005). The current patterns and variations of water and sediment flows in the Mekong River are critical to sustaining agriculture and fisheries that support the livelihoods and nutrition of millions of people in the basin (MRC, 2010). However, natural water and sediment flows in the Mekong River and its tributaries are under threat by ongoing hydropower development (Grumbine and Xu, 2011; Kummu and Varis, 2007; MRC, 2011a). The construction of large dams in the Lancang River have caused suspended sediment reduction in the Upper Mekong (Fu et al., 2008) and evidence of changes in water level induced by historical water infrastructure development in the Mekong has been reported by Cochrane et al. (2014).

Cumulative impact assessments have studied how ongoing and future hydropower development could alter flow regimes in the Mekong River mainstream (Lauri et al., 2012; Piman et al., 2013b) with consequent ecosystem, social, and economic impacts (Arias et al., 2014a; Kubiszewski et al., 2012; Lauri et al., 2012; Orr et al., 2012; Piman et al., 2013b). Hydrological assessments indicated that increased hydropower development levels will result in an increase of flows in the dry season, a decrease in flows in the wet season, and a reduction in the amplitude of flood peaks (Lauri et al., 2012; Piman et al., 2013b). Nevertheless, the predicted magnitude of alterations varies between studies as a function of the simulation time frame, scenarios, assumptions, and the models used (Johnston and Kummu, 2011). For example, Lauri et al. (2012) used one future development scenario that represented all future hydropower development proposed in the Mekong, whereas Piman et al. (2013b) assessed different levels of hydropower development in combination with other forms of water infrastructure.

Furthermore, the discussion and predictions of disruptions to sediment delivery caused by dam development have been increasing in recent years. The mean annual trapping efficiency of existing and commissioned dams has been estimated to be $15-51 \%$, and the overall trapping efficiency could increase to 51-96\% when all the proposed hydropower dams in the Mekong Basin are built (Kondolf et al., 2014; Kummu et al., 2010). Predicted changes induced by hydropower development are causing a growing concern among local communities and international observers, because alterations to natural flows and sediment patterns could result in irreversible damage to downstream ecology, habitats, agriculture, and fisheries as evidenced with large dams all around the world (WCD, 2000). As most hydropower development is occurring in Mekong tributaries, detailed studies of the impact of development level, siting, and operations is need in key sub-basins. 
The transboundary Srepok, Sesan and Sekong (3S) Rivers form a key sub-basin of the Mekong undergoing rapid hydropower development (Piman et al. 2013a). The 3S basin straddles Cambodia, Laos, and Vietnam, covers an area of 78,650 $\mathrm{km}^{2}$, and contributes up to $20 \%$ of the Mekong's total annual flow $\left(91,000 \times 10^{6} \mathrm{~m}^{3}\right.$ or an average of $\left.2,886 \mathrm{~m}^{3} / \mathrm{s}\right)$, which is the largest flow contribution among tributaries. The $3 \mathrm{~S}$ plays an important role in aquatic biodiversity, ecosystem services and fish production in the lower Mekong, particularly with regards to water flows, suspended sediments, nutrients, fish habitats and migration routes (Arias et al., 2014b; Wild and Loucks, 2014; Ziv et al., 2012). Of immediate concern is the potential impact of accelerating hydropower development in the $3 \mathrm{~S}$ (Figure 1), which all together could yield alterations of similar magnitude as those caused by the large cascade of dams in the Upper Mekong (Arias et al., 2014b; Piman et al., 2013a)

Hydropower potential in the Vietnam Highlands of the Sesan and Srepok Rivers is fully developed with a total installed capacity of 2,519 MW and a total active storage of 3,148 x $10^{6}$ $\mathrm{m}^{3}$, consisting of individual dams and cascade dams. About six dams are currently operating or under construction in Lao PDR in the Sekong basin with a total installed capacity of 1,172 MW and a total active storage of 3,460 x $10^{6} \mathrm{~m}^{3}$. Only one small hydropower dam exists in Cambodia. Twenty one projects are in planning stages in Lao PDR and Cambodia, with a total installed capacity of 2,671 MW and a total active storage of $19,712 \times 10^{6} \mathrm{~m}^{3}$. Some of these are prioritized to be developed in the next 2-5 years, such as Xekong 5 in Lao PDR and the Lower Sesan and Srepok 2 in Cambodia, where construction has already started. The status, installed capacity and active storage of the hydropower projects in the $3 \mathrm{~S}$ is presented in Figure 1 and detailed characteristics of each project are provided in Table 1 (with data from MRC, 2009).

The operation of existing large hydropower dams in the upper reaches of the $3 \mathrm{~S}$ has already had severe negative impacts on downstream communities in Vietnam and across the border in Lao PDR and Cambodia, where extreme water level fluctuations have affected water quantity and quality and decreased fish stocks (Cronin and Hamlin, 2012; Wyatt and Baird, 2007). Piman et al. (2013a) indicated that the operation of all current and proposed hydropower projects in the $3 \mathrm{~S}$, under a regime to maximize energy production, will alter flow regimes significantly at the outlet of the basin and in the Mekong mainstream by redistributing water from the wet to the dry season. The impacts of full hydropower development in the $3 \mathrm{~S}$ are comparable to changes induced by the current development of large dams in the Upper Mekong Basin in China (Piman et al., 2013a). Furthermore, Arias et al., (2014b) indicated that the full development of the $3 \mathrm{~S}$ dam network will most likely cause large hydrological alterations to the Tonle Sap. A water resources study conducted by ADB (2010) in the 3S basin also indicated that flow alterations in the next 20 years will still be dominated by hydropower (higher dry season flows and lower wet season flows), among alterations caused by multiple water infrastructure types. Results from ADB (2010), Piman et al. (2013a) and Arias et al. (2014b) focused on cumulative impact assessments, but the contribution of individual dams on flow changes and energy production were not demonstrated. Dam operation rules used for those studies were defined independently to maximize energy and did not take into account cascade dam effects. Evaluating difference between standalone operations, individual operations within a cascade of dams, and cascade operations will help determine the overall benefit or impact of each proposed dam in terms of energy production and alteration of water flows.

The main objective of this paper is therefore to determine how the operation of the proposed largest individual dams and cascade dams schemes in the $3 \mathrm{~S}$ tributary will affect flow regimes and energy production. The marginal effect of developing individual dams is compared to 
cumulative impacts induced by existing and future hydropower development in the $3 \mathrm{~S}$. Furthermore, the impacts of cascade dams are examined and compared against individual dam in terms of energy production and downstream flow changes.

\section{Methodology and data used}

Hydrological processes and hydropower production in the $3 \mathrm{~S}$ were simulated using the Soil and Water Assessment Tool (SWAT; Winchell et al., 2010) and the US Army Corps of Engineers HEC-ResSim model (Klipsch and Hurst, 2013) for a range of hydropower development and operations scenarios. Large proposed dams were defined based on their installed capacity and active storage. Individual and cascade dam operation rules were defined using a linear optimization model to maximize energy production. Flows were simulated over a period of 20 years using observed climate data from 1986 to 2005. This simulation period was selected based on i) availability and completeness of observed climate and flow data and ii) representativeness of a wide range of hydrological variation in the basin. The selected period contains extreme drought events (1988, 1992 and 1998) and flood events (2000, 2001 and 2002).

\section{Definition of the large dams}

This study focused on the impact assessment of proposed large hydropower projects, defined as those with an installed electricity generation capacity above $300 \mathrm{MW}$ and/or an active water volume storage over $1,000 \times 10^{6} \mathrm{~m}^{3}$. Overall, seven proposed dams in the $3 \mathrm{~S}$ basin met the criteria: Lower Srepok 3, Lower Srepok 4, Lower Sesan 3, Lower Sesan/Srepok 2, Xekong 5 , Xekong 4, and Xe Xou (Figure 2). The impacts on flow and energy production of all seven dams were assessed individually. The effects of cascade dam operations in terms of flow changes and energy production were also considered for the Lower Srepok 3, Lower Srepok 4, Lower Sesan 3, and Lower Sesan/Srepok 2 projects in Cambodia and the Xekong 5 and Xekong 4 in Lao PDR (Figure 3). The ratio of active storage to mean annual flow volume (S/V ratio) at the $3 \mathrm{~S}$ outlet $\left(91,000 \times 10^{6} \mathrm{~m}^{3}\right)$ shown in Table 1 also supports our definition of large dams. It shows that Lower Srepok 3 dam has the highest S/V ratio (5.84\%) which means its ability to control river flows is therefore greater than other dams in the basin.

\section{Hydrological simulation}

SWAT was selected as the numerical model for hydrological simulations in this study. Apart from its proven ability to simulate flows, SWAT was chosen because it is already used by the MRC and it has been recently updated and calibrated with recent observed flow data (MRC, 2011b). The SWAT model is part of the MRC Decision Support Framework (DSF), which was accepted by MRC member countries for water resources planning in the Lower Mekong Basin (MRC, 2004). The physical data (topography, soils and land cover) and observed climate data (rainfall, temperature, relative humidity, wind speed and solar radiation) from 1986-2005 were input in the SWAT model to simulate daily flows from 118 sub-basins in the $3 \mathrm{~S}$. Physical data were used to define Hydrologic Response Units (HRUs) in the sub-basins. Flows to the main channel from each sub-basin were calculated based on climate data and HRUs and routed through the channel network to the basin's outlet (Winchell et al., 2010). Six flow gauges in the $3 \mathrm{~S}$ and two in the Mekong mainstream were used to calibrate the model parameters. The calibrated flows from the $3 \mathrm{~S}$ basin at the Mekong mainstream station (Stung Treng) were comparable to the observed data for the same time period (Figure 4), achieving a coefficient of efficiency of 0.94 with the Nash-Sutcliffe goodness of fit coefficient (Nash and Sutcliffe, 
1970). Overall, the calibrated flows are close to the observed flows in term of volumes, peak flows and low flows during the calibration period..

\section{Reservoir simulation}

USACE's HEC-ResSim model was selected for simulation of hydropower operations and reservoir routing due to its greater ability to model multi reservoir systems for a variety of operational goals and constraints compared to other available models such as IQQM, MIKE Basin and WEAP models. The model is capable of simulating reservoir operations for hydropower production, flood management, low flow regulation, and can be used for developing detailed reservoir regulation plans (Klipsch and Hurst, 2013). The HEC-ResSim model was also chosen because it has been under development for a number of years and continues to be used for environmental impact assessments in the $3 \mathrm{~S}$ basin (Cochrane et al., 2010; Piman et al., 2013a). Simulated flows for each sub-basin from SWAT were lumped at the dam sites (Figure 1) and used as input to the HEC-ResSim model to simulate regulated daily flows and energy production from dam operations. Physical characteristics and dam operation rules were required input data for the model and these were obtained from the MRC hydropower database (Table 1; updated from MRC 2009). Water level-area-volume curves for the reservoirs were developed from information provided in the MRC hydropower database, but for specific cases where these data were not available, the curves were estimated using a $50 \mathrm{~m}$ resolution digital elevation model (DEM). The Muskingum-Cunge method, in which channel cross-section geometry was defined by eight points, was selected for river channel routing (Klipsch and Hurst, 2013).

\section{Reservoir operation rules}

An independent operation rule was defined for each individual dam in order to maximize energy production by controlling releases and water storage in the reservoir based on simulated natural inflows. Simulated water inflows from SWAT and dam characteristics (active storage of the reservoir, plant characteristics, reservoir volume-elevation relationship, tail water level, installed capacity and design discharge of the plants) were input to a linear optimization model (Dat, 2009) to calculate a target reservoir water level for each month. The objective functions for model optimization were to i) maximize annual energy generation, ii) avoid running the reservoir dry before the end of the dry season, and iii) minimize the risk of excess spillage due to the reservoir being full before the end of the wet season. The first objective was used to define an upper rule curve that balances the gains in energy production resulting from operating at high reservoir levels and the losses of energy resulting from spilled water. The second and third objectives were used to determine the minimum monthly storage that must be maintained during operation of the reservoir (lower rule curve). This calculation required information on inflow water volumes and the active storage of the reservoir. The operation rule for the dam was then calculated by linear interpolation between upper and lower rule curves.

A coordinated or joint operation rule was implemented in HEC-ResSim to maximize energy production for the three cascade systems (Figure 3) by taking into account the reservoir storage balance between upstream and downstream dams. The system storage was determined by the sum of the total storage of the upstream and downstream reservoirs. The desired storage for each reservoir was then determined through an implicit balance line which was simply a linear relationship between storage in each reservoir and the system storage (Klipsch and Hurst, 
2013). The balance line represents an equal percentage of each reservoir to the desire storage. When the storage in a particular reservoir is above its desired storage, water release is prioritized in order to reduce storage as close as possible to the desired storage level, unless other constraints (such as maximum physical outlet capacity) restrict flow releases. In contrast, when the storage in a particular reservoir is below its desired storage, it is force to cut back its releases so that storage can rise to the desire storage level or as close as possible to the desired level.

\section{Simulated scenarios}

Four hydropower development scenarios were simulated under the independent operation rule to investigate the degree of changes in flows and energy production from the proposed large hydropower projects. Each scenario is explained below and a list of hydropower projects for each scenario is provided in Table 1.

1) Baseline scenario (BL): refers to the natural, unregulated flow conditions. No hydropower projects are included in this scenario.

2) Definite Future scenario (DF): refers to the current stage of hydropower development as of 2013. This scenario includes existing and ongoing hydropower construction projects (20 projects).

3) Individual Dam scenarios (ID): includes the developments in the DF plus each of the proposed large dams. This scenario is run a total of seven times, one run for each large dam.

4) All Dams scenario (AD): includes all current and proposed hydropower development in the $3 \mathrm{~S}$ (a total of 41 projects)

Furthermore, cascade systems in the Definite Future and All Dams scenarios were simulated using a joint (coordinated) operation rule to examine their impacts on the flows and energy production compared with simulations using independent operation rules. The three cascade systems were selected for simulations as illustrated in Figure 3. The Lower Sesan/Srepok 2 (downstream of the Sesan and Srepok Rivers confluence) was considered to cascade with the Lower Sesan 3 and the Lower Srepok 3. The Lower Srepok 3 and the Lower Srepok 4 in the Srepok River was considered as another cascade system. The third cascade system was composed of the Xekong 4 and the Xekong 5 in the Sekong River.

\section{Results}

Simulated flows at the $3 \mathrm{~S}$ outlet from the Baseline and Definite Future scenarios were compared against simulated flows from the Individual Dams scenarios and the All Dams scenario to examine relative changes as presented in Figure 5. Average dry season flows (Dec. to May), wet season flows (Jun. to Nov.), daily maximum flows, and daily minimum flows over the 20 years (1986-2005) as well as the annual energy production for the different hydropower development scenarios were compared and presented in Table 2. The ratio of incremental change in installed capacity and average dry season flows of the Individual Dams scenarios from the Definite Future scenario were calculated and plotted in Figure 6 in order to show diminishing returns of the seven large dams. The impacts of the cascade dam systems on reservoir operations and energy production were compared to individual dam simulations (Figures 7 and 8). 


\section{Impact of current hydropower development (Definite Future scenario)}

The Definite Future scenario results in an expected increase of dry season and minimum flows and a decrease of wet season and maximum flows. Compared to the Baseline scenario, average dry season flows and average daily minimum flows increase by $28.2 \%$ and $76.9 \%$, respectively (Table 2). Moreover, average wet season flows and average daily maximum flows decrease by $7.0 \%$ and $13.5 \%$, respectively. Changes in flow regimes in the Definite Future scenarios are mainly caused by full hydropower development in the Vietnam Highlands (Figure 1). The energy production in the Definite Future scenario is $73.2 \mathrm{GWh} /$ day. About $64 \%$ of electricity was generated by hydropower projects in the Vietnam Highlands and the remaining $36 \%$ was produced in Laos.

\section{Impact of the large proposed dams (Individual Dam scenarios)}

Among the large dams considered in the Individual dam scenarios, the Lower Srepok 3 in Cambodia, with active storage of 5,310 million $\mathrm{m}^{3}$, was found to have the highest effect on flow alterations at the $3 \mathrm{~S}$ outlet. When compared to the Definite Future scenario, the proposed Lower Srepok 3 will increase flows in the dry season by $22.1 \%$ and decrease wet season flows by $5.9 \%$ (Figure 5). The Xekong 4 dam in Laos, with an active storage of 3,100 million $\mathrm{m}^{3}$, also shows high potential for flow alterations. This project will increase the dry season flows by $15.6 \%$ and reduce the wet season flows by 3.6\%. The Lower Sesan/Srepok 2 in Cambodia shows the lowest effect on flow regimes among proposed large dams. Overall, all Individual dam scenarios were found to decrease average maximum daily flows by $2.0-13.7 \%$ and increase minimum daily flows by $6.8-42.2 \%$ at the $3 \mathrm{~S}$ basin outlet into the Mekong.

Electricity generation of these seven large proposed dams varies from 1.5 to $6.8 \mathrm{GWh} / \mathrm{day}$ (Table 2). The Lower Sesan/Srepok 2 produced the highest electricity output $(6.8 \mathrm{GWh} /$ day $)$ followed by the Xekong 5 ( $6.0 \mathrm{GWh}$ /day) and the Lower Sesan 3 (5.8 GWh/day). In total, the seven large proposed dams will further increase energy production in the $3 \mathrm{~S}$ by $45 \%(33.0$ GWh/day) from the Definite Future scenario.

The Lower Sesan/Srepok 2 gives the highest return in term of installed capacity with the lowest impact on changing dry season flows compared with other large dams (Figure 6). In contrast, the Lower Srepok3 gives the lowest return with the highest impact on changing dry season flows.

\section{Impact of full hydropower development}

The All Dams scenario in the 3S shows substantial effects on flow regimes in both wet and dry seasons. The development of all proposed hydropower projects will further decrease the average maximum daily flows from the Definite Future scenario by $36.3 \%$ and increase the average minimum daily flows by $167.6 \%$ (Table 2 ). When compared to the Baseline scenario, the average dry season flows under the All Dams scenario nearly doubles $(88.1 \%)$ while the average wet season flows decrease by $24.7 \%$. The large changes in flow regimes in this scenario are mainly due to the seven large proposed dams; total active storage in the Definite Future scenario is only $6,616 \times 10^{6} \mathrm{~m}^{3}$ while the cumulative active storage of the seven large proposed dams is $17,679 \times 10^{6} \mathrm{~m}^{3}$ and the cumulative active storage of the other 14 proposed dams is only 2,033 $\times 10^{6} \mathrm{~m}^{3}$. The total active storage of the All Dams scenario reaches 26,328 $\mathrm{x} 10^{6} \mathrm{~m}^{3}$ which is about $30 \%$ of the average annual flow at the outlet of the $3 \mathrm{~S}\left(91,000 \times 10^{6}\right.$ 
$\mathrm{m}^{3}$ ). The total energy production in the All Dams scenario would increase to $129.1 \mathrm{GWh} /$ day, which is nearly double the amount of electricity generated under the Definite Future scenario.

\section{Impact of cascade dams}

The effects of development of upstream cascade dams on the Lower Sesan/Srepok 2, the Lower Srepok 3 and the Xekong 4 dams' energy production and outflows were quantified. For the initial simulations, each dam in the cascade was managed under independent operations rules. The simulated reservoir levels of the Lower Sesan/Srepok 2, the Lower Srepok 3 and the Xekong 4 increased when the cascade dams were introduced, particularly in the dry season (Figure 4). The reservoir levels of the Xekong 4 and the Lower Sesan/Srepok 2 were strongly affected by the operations of the upstream cascade dams, while the Lower Srepok 3 was only slightly impacted. The cascade systems not only influence downstream reservoir operations and outflows, but also energy production. The energy production of the Xekong 4 and the Lower Sesan/Srepok 2 almost doubled, while the energy production of the the Srepok 3 increased only a small amount (Figure 5). When three cascade dams were simulated using a joint operation rule, there was a marginal increase in productivity of $5 \%$ at most.

\section{Discussion}

The existing and ongoing projects in the Definite Future scenario have a total installed capacity of 3,691 MW (58\% of full potential) with only a total active storage of $6,616 \times 10^{6} \mathrm{~m}^{3}$, while the 21 proposed projects will provide an additional total installed capacity of 2,672 MW, but will require a total active storage of $19,712 \times 10^{6} \mathrm{~m}^{3}$ (three times the total active storage used in the Definite Future scenario). This suggests that the first half of power production requires little storage capacity while the second half of power production requires a very large storage capacity. Most hydropower projects in the Definite Future scenario are in the higher parts of the catchment and were designed as run-of-the-river dams having small storage reservoirs; thus, predicted alterations to seasonal flows caused by this scenario are relatively low compared to the potential future development of dams in the lower catchment which will have lower generation head capacities and require larger reservoirs.

The additional energy production of the seven large proposed dams is $33.0 \mathrm{GWh} /$ day, which is less than half of the cumulative production in the Definite Future scenario ( $73.2 \mathrm{GWh} / \mathrm{day})$. The cumulative active storage of the seven large proposed dams $\left(17,679 \times 10^{6} \mathrm{~m}^{3}\right)$, however, is nearly three times larger than the total active storage in the Definite Future scenario $(6,616$ $\mathrm{x} 10^{6} \mathrm{~m}^{3}$ ), which highlights their low electricity generation efficiency. Reservoir operations of the Lower Srepok 3, Lower Srepok 4, Lower Sesan 3, Xekong 5, Xekong 4, and Xe Xou dams, in particular, will have a significant effect on downstream flows because they have large reservoirs intended to capture water during the wet season and release it during the dry season. These projects are the most critical as they will be responsible for the majority of flow alterations in the $3 \mathrm{~S}$ basin, which will likely impact downstream water quality, sediment, habitats, fisheries and livelihoods.

Kummu et al.(2010) and Wild and Loucks (2014) indicate that proposed dams in the 3S basin are expected to trap $40-80 \%$ of total sediment transportation over the whole basin. Reducing of sediment delivery downstream will impact on river morphology, aquatic biodiversity, ecosystem services, and agriculture (through reduced nutrient fertilization from sediments). Therefore, detailed studies on impacts of hydropower development on sediment and how to 
pass sediment through the dams are necessary for preparing sediment management plans and strategies in the basin.

Amongst the proposed large dams, the Lower Sesan/Srepok 2 in Cambodia is expected to have the smallest effect on the flow regime downstream and it will produce the largest electricity output. At a first glance, this dam could be considered the best of the large hydropower projects in terms of maximum benefit on energy production and minimum impacts to the natural flow regime. However, considering the location of the dam, which is located near the outlet of the $3 \mathrm{~S}$, this dam will block key fish migration routes to the upper Sesan and Srepok Rivers. Our research in conjunction of that of Ziv et al. (2012) demonstrates that overall basin hydropower generation will not be drastically affected if the Lower Sesan/Srepok 2 and the Xekong cascade -which are highly detrimental to fish migrations- were avoided. Given the relatively low electricity potential of the seven large dams in comparison with their disproportionately high risk for hydrological alterations and subsequent detrimental effects, their conception must be critically analyzed beyond economic benefits to a single investor, and instead, a greater, basinwide evaluation of benefits and tradeoffs among all stakeholders must take place to warrant good guidance for decision makers.

Cascade schemes above the Lower Sesan/Srepok 2 and Xekong 4 where shown to increase the individual energy productivity of those particular dams. The cascade dam scheme on the Srepok resulted in only a minor increase in electricity generation at the Srepok 3 dam. The small gain at this dam when operated as a cascade is mainly due to the relatively small active storage in the upstream dam reservoir, Srepok $4\left(10.1 \times 10^{6} \mathrm{~m}^{3}\right)$, in contrast to the much larger active storage in the upstream dam reservoirs of the other two cascades $\left(1,356 \times 10^{6} \mathrm{~m}^{3}\right.$ in the Xekong and $5430 \times 10^{6} \mathrm{~m}^{3}$ in the Lower Sesan/Srepok). Appropriate water storage volumes in upstream dams is a fundamental condition for implementing adequate cascade hydropower operation rules (Lund and Guzman, 1999). Hydropower generation has been shown to increase when such conditions are met (Zhou et al., 2015). Although the added benefit of potential energy production can be seen as an incentive to build more dams and a way to improve the productivity of some of the large seven dams, further analysis is needed on the timing between electricity supply (increase generation potential from dams) and electricity demand (peak demand times in the buying market). Albeit the marginal increase in efficiency (up to 5\% increase in electricity generation) when cascade dams are operated jointly, the actual logistics of this operation scheme may prove to be difficult if dams are operated by different companies and under different purchase agreements.

While there are opportunities to mitigate flow alterations by modifying hydropower operation rules (Piman et al., 2013a; Richter and Thomas, 2007), further research is needed on optimizing operation rules of dams in this region in order to fulfill electricity demand without drastic impacts to downstream river and floodplain ecosystems. Thus far, what is clear from research on the 3S dams (Arias et al., 2014b; Piman et al., 2013a) and the Lancang River cascade in the Upper Mekong Basin (Li et al., 2012; Räsänen et al., 2012) is that the magnitude of hydrological alterations increases proportionally to the number of dams and cumulative active storage.

Piman et al (2013) indicated that full hydropower development in the $3 \mathrm{~S}$ can cause significant change to flows in the Mekong mainstream. The predicted changes of the magnitude at Kratie in Cambodia (200 km downstream of $3 \mathrm{~S}$ outlet) are similar to the impacts caused by hydropower development in the Upper Mekong Basin. Dry season flows in February are predicted to increase by 860 and $812 \mathrm{~m}^{3} / \mathrm{s}$ (about $31 \%$ ) from baseline condition $\left(2,710 \mathrm{~m}^{3} / \mathrm{s}\right.$ ) 
under full hydropower development in the $3 \mathrm{~S}$ and hydropower development in the Upper Mekong Basin, respectively. Wet season flows are predicted to decrease by about $5 \%$ from baseline condition in both cases. Our study has demonstrated that the majority of these changes in the $3 \mathrm{~S}$ basin will come from the proposed development of seven large dams. Significant hydrological alterations in the Mekong mainstream from combined hydropower development in the $3 \mathrm{~S}$ basin and China would alter the hydrology of the Tonle Sap's Floodplain, the largest wetland in the Mekong and home to one of the most productive inland fisheries in the world (Arias et al., 2014b; Piman et al., 2013a).

Future irrigation water demands, land use change, and climate change have been studied in this basin before (Piman et al., 2015; Räsänen et al., 2015; Ty et al., 2012); thus, these factors were not considered in this study. Their complementary (or conflicting) effects with hydropower, however, are important for water resources management and should be the subject of further research. Thus far, water withdrawals for agricultural production have not been found to be conflicting significantly with hydropower in this basin (Räsänen et al., 2015). Preliminary modelling on climate change and hydropower operations suggests that hydropower operations have the greatest impact on seasonal flow patterns, and that energy production will not be substantially affected by impacts of climate change on basin hydrology (Piman et al., 2015). Coordinated irrigation and external water storage may help offset seasonal flow alterations, but this will depend on the magnitude of irrigation demands, land use change, and their coordination with energy demands for national consumption and exports, this later being the main objective of proposed electricity generation in Laos and Cambodia (MRC, 2010).

While it was not explicitly simulated and presented in this paper, intra-daily reservoir operations from existing and soon to be operated dams may significantly increase sub-daily flow fluctuations, harming riparian livelihoods and ecosystems downstream. Hourly variations have been observed to affect local communities in the vicinity of existing $3 \mathrm{~S}$ dams (Wyatt and Baird, 2007), and examples of how hourly variations can result in basin-wide alterations have been observed elsewhere (Zimmerman et al., 2010). Further research, policy, and management should focus on improving dam operations, design, and coordination between stakeholders in order to manage risks and maximize basin benefits. Given the rate of development, its transboundary nature, and its importance to maintaining Mekong river flow patterns, the establishment of an inter-government basin committee for the 3S Rivers is probably warranted, potentially under the auspices of the MRC. Immediate agreements on sharing information and developing warning systems downstream of the existing and under construction dams are also required.

\section{Conclusions}

Development of all dams in the $3 \mathrm{~S}$ and operations to maximize energy production will significantly reduce the difference between wet and dry season flows. Changes in flow regimes at the outlet of the 3S will mainly be caused by the Lower Srepok 3, Lower Srepok 4, Lower Sesan 3, Xekong 5, Xekong 4, Lower Sesan/Srepok 2, and Xe Xou hydroelectric projects. Among these, the Lower Sesan 3 in Cambodia, followed by the Sekong 4 in Laos are expected to bring the largest alterations to dry season and wet season flows. Energy production in a definite future scenario of development (current and under construction dams) will generate $73.2 \mathrm{GWh} /$ day with an active reservoir water volume of $6,616 \mathrm{million}^{3}$, and development of the seven largest dams will generate an additional $33.0 \mathrm{GWh} /$ day, but with a water volume of 17,679 million $\mathrm{m}^{3}$. Potential effects of all seven large dams on water flows, with relatively 
small gains in overall energy production compared to the substantial increase in active storage, indicate that they should be further scrutinized in term of their individual and combined economic, environmental, and wider social impacts, before premature decisions are made to implement them. If these large dams are eventually commissioned (as the Lower Sesan/Srepok 2 was in 2013), implementation of sustainable practices in their design, operations, and catchment management will be necessary to help alleviate undesirable environmental impacts. In searching for more appropriate electricity generation alternatives, small hydropower projects proposed on sub-tributaries of the $3 \mathrm{~S}$ rivers have a much smaller impact on flow changes (Piman et al., 2013b) and have a higher ratio of energy to active storage when compared to the proposed large dams; thus, a careful consideration of the individual contribution from each proposed dam to basin-wide benefits and impacts is needed in order to select the best alternatives for economic development of hydropower in the $3 \mathrm{~S}$ while reducing social and environment impacts.

\section{Acknowledgments}

Funding for University of Canterbury was provided by John D. and Catherine T. MacArthur Foundation through a project entitled "Critical Basin at Risk: Assessing and managing ecosystem pressures from development and climate change in the $3 \mathrm{~S}$ basin". This manuscript was completed while M. E. Arias was a Giorgio Ruffolo Fellow in the Sustainability Science Program at Harvard University and the support from Italy's Ministry for Environment, Land and Sea is gratefully acknowledged. The Mekong River Commission contributed historical flows and climatic data.

\section{References}

Adamson, P.T., Rutherfurd, I.D., Peel, M.C., Conlan, I.A., 2009. The Hydrology of the Mekong River, in: The Mekong. Academic Press, San Diego, pp. 53-76.

ADB, 2010. Sesan, Sre Pok, and Sekong River Basins Development Study in Kingdom of Cambodia, Lao People's Democratic Republic, and Socialist Republic of Viet Nam (Final Technical Assistance Report No. TA6367).

Arias, M.E., Cochrane, T.A., Kummu, M., Lauri, H., Koponen, J., Holtgrieve, G.W., Piman, T., 2014a. Impacts of hydropower and climate change on drivers of ecological productivity of Southeast Asia's most important wetland. Ecological Modelling 272, 252-263.

Arias, M.E., Piman, T., Lauri, H., Cochrane, T.A., Kummu, M., 2014b. Dams on Mekong tributaries as significant contributors of hydrological alterations to the Tonle Sap Floodplain in Cambodia. Hydrology and Earth System Sciences 18, 5303-5315. doi:10.5194/hess-18-5303-2014

Carling, P.A., 2009. The Geology of the Lower Mekong River, in: The Mekong. Academic Press, San Diego, pp. 13-28.

Cochrane, T.A., Arias, M.E., Piman, T., 2014. Historical impact of water infrastructure on water levels of the Mekong River and the Tonle Sap system. Hydrol. Earth Syst. Sci. 18, 4529-4541. doi:10.5194/hess-18-4529-2014

Cochrane, T.A., Arias, M.E., Teasley, R.L., Killeen, T.J., 2010. Simulated changes in water flows of the Mekong River from potential dam development and operations on the Se San and Sre Pok tributaries, in: IWA World Water Congress and Exhibition. Presented at the IWA World Water Congress and Exhibition, Montreal, Canada.

Cronin, R., Hamlin, T., 2012. Mekong turning point: shared river for a shared future. Henry L. Stimson Center. 
Dai, A., Trenberth, K.E., 2002. Estimates of freshwater discharge from continents: Latitudinal and seasonal variations. Journal of hydrometeorology 3, 660-687.

Dat, N.D., 2009. Rule curve for hydropower dam using with IQQM model:User's Manual Version 1D. Mekong River Commission, Vientiane, Lao PDR.

Delgado, J.M., Apel, H., Merz, B., 2010. Flood trends and variability in the Mekong river. Hydrology and Earth System Sciences 14, 407-418.

Delgado, J.M., Merz, B., Apel, H., 2012. A climate-flood link for the lower Mekong River. Hydrology and Earth System Sciences 16, 1533-1541. doi:10.5194/hess-16-15332012

Fu, K.D., He, D.M., Lu, X.X., 2008. Sedimentation in the Manwan reservoir in the Upper Mekong and its downstream impacts. Quaternary International 186, 91-99.

Grumbine, R.E., Xu, J., 2011. Mekong Hydropower Development. Science 332, 178-179. doi: $10.1126 /$ science. 1200990

Johnston, R., Kummu, M., 2011. Water Resource Models in the Mekong Basin: A Review. Water Resources Management 26, 1-27. doi:10.1007/s11269-011-9925-8

Klipsch, J.D., Hurst, M.B., 2013. HEC - ResSim Reservoir System Simulation Version 3.1 User Manual (Computer Program Documentation). US Army Corps of Engineers Institute for Water Resources Hydrologic Engineering Center, Davis, CA (USA).

Kondolf, G.M., Rubin, Z.K., Minear, J.T., 2014. Dams on the Mekong: Cumulative sediment starvation. Water Resour. Res. 50, 5158-5169. doi:10.1002/2013WR014651

Kubiszewski, I., Constanza, R., Paquet, P., Halimi, S., 2012. Hydropower development in the lower Mekong basin: alternative approaches to deal with uncertainty. Regional Environmental Change 10. doi:10.1007/s10113-012-0303-8

Kummu, M., Lu, X.X., Wang, J.J., Varis, O., 2010. Basin-wide sediment trapping efficiency of emerging reservoirs along the Mekong. Geomorphology 119, 181-197. doi:10.1016/j.geomorph.2010.03.018

Kummu, M., Varis, O., 2007. Sediment-related impacts due to upstream reservoir trapping, the Lower Mekong River. Geomorphology 85, 275-293.

Lauri, H., de Moel, H., Ward, P.J., Räsänen, T.A., Keskinen, M., Kummu, M., 2012. Future changes in Mekong River hydrology: impact of climate change and reservoir operation on discharge. Hydrol. Earth Syst. Sci. 16, 4603-4619. doi:10.5194/hess-164603-2012

Li, J., Dong, S., Yang, Z., Peng, M., Liu, S., Li, X., 2012. Effects of cascade hydropower dams on the structure and distribution of riparian and upland vegetation along the middle-lower Lancang-Mekong River. Forest Ecology and Management 284, 251259.

Lund, J.R., Guzman, J., 1999. Derived operating rules for reservoirs in series or in parallel. Journal of Water Resources Planning and Management 125, 143-153.

MRC, 2011a. IWRM-Based Basin Development Strategy for the Lower Mekong Basin 20112015. Mekong River Commission, Vientiane, Lao PDR.

MRC, 2011b. Application of MRC modeling tools in the 3S basin (Main Report). Mekong River Commission, Phnom Penh, Cambodia.

MRC, 2010. State of the Basin Report 2010. Mekong River Commission, Vientiane, Lao PDR.

MRC, 2009. Hydropower Project Database. Mekong River Commission, Vientiane, Lao PDR.

MRC, 2005. Overview of the hydrology of the Mekong Basin. MRC, Vientiane, Lao PDR.

MRC, 2004. Decision Support Framework: Main Report, Water Utilization Programme, Mekong River Commission, Vientiane, Lao. MRC, Vientiane, Lao PDR. 
Nash, J.E., Sutcliffe, J.V., 1970. River flow forecasting through conceptual models part I A discussion of principles. Journal of Hydrology 10, 282-290. doi:10.1016/00221694(70)90255-6

Orr, S., Pittock, J., Chapagain, A., Dumaresq, D., 2012. Dams on the Mekong River: Lost fish protein and the implications for land and water resources. Global Environmental Change 22, 925-932. doi:10.1016/j.gloenvcha.2012.06.002

Piman, T., Cochrane, T.A., Arias, M.E., Green, A., Dat, N.D., 2013a. Assessment of Flow Changes from Hydropower Development and Operations in Sekong, Sesan and Srepok Rivers of the Mekong Basin. Journal of Water Resources Planning and Management 139, 723-732. doi:10.1061/(ASCE)WR.1943-5452.0000286

Piman, T., Cochrane, T., Arias, M.E., Dat, N., Vonnarart, O., 2015. Managing Hydropower Under Climate Change in the Mekong Tributaries, in: Shrestha, S., Anal, A.K., Salam, P.A., van der Valk, M. (Eds.), Managing Water Resources under Climate Uncertainty, Springer Water. Springer International Publishing, pp. 223-248.

Piman, T., Lennaerts, T., Southalack, P., 2013b. Assessment of hydrological changes in the lower Mekong basin from basin-wide development scenarios. Hydrol. Process. 27, 2115-2125. doi:10.1002/hyp.9764

Räsänen, T.A., Koponen, J., Lauri, H., Kummu, M., 2012. Downstream Hydrological Impacts of Hydropower Development in the Upper Mekong Basin. Water Resources Management 26, 3495-3513. doi:10.1007/s11269-012-0087-0

Räsänen, T., Joffre, O., Someth, P., Thanh, C., Keskinen, M., Kummu, M., 2015. ModelBased Assessment of Water, Food, and Energy Trade-Offs in a Cascade of Multipurpose Reservoirs: Case Study of the Sesan Tributary of the Mekong River. J. Water Resour. Plann. Manage. 141. doi:10.1061/(ASCE)WR.1943-5452.0000459

Richter, B.D., Thomas, G.A., 2007. Restoring Environmental Flows by Modifying Dam Operations. Ecology and Society 12.

Ty, T.V., Sunada, K., Ichikawa, Y., Oishi, S., 2012. Scenario-based Impact Assessment of Land Use/Cover and Climate Changes on Water Resources and Demand: A Case Study in the Srepok River Basin, Vietnam-Cambodia. Water Resources Management 26, 1387-1407. doi:10.1007/s11269-011-9964-1

WCD, 2000. Dams and development. A new framework for decision-making. The report of the World Commission on Dams. Earthscan Publications Ltd, London and Sterling, VA.

Wild, T.B., Loucks, D.P., 2014. Managing Flow, Sediment, and Hydropower Regimes in the Mekong River Basin. Water Resources Research 50, 5141-5157. doi:10.1002/2014WR015457

Winchell, M., Srinivasan, R., Di Luzio, M., Arnold, J., 2010. ArcSWAT Interface for SWAT2009: User's Guide. Temple, Texas (USA).

Wyatt, A.B., Baird, I.G., 2007. Transboundary Impact Assessment in the Sesan River Basin: The Case of the Yali Falls Dam. International Journal of Water Resources Development 23, $427-442$.

Zhou, Y., Guo, S., Xu, C.-Y., Liu, P., Qin, H., 2015. Deriving joint optimal refill rules for cascade reservoirs with multi-objective evaluation. Journal of Hydrology 524, 166181.

Zimmerman, J.K.H., Letcher, B.H., Nislow, K.H., Lutz, K.A., Magilligan, F.J., 2010. Determining the effects of dams on subdaily variation in river flows at a whole-basin scale. River Research and Applications 26, 1246-1260. doi:10.1002/rra.1324

Ziv, G., Baran, E., Nam, S., Rodriguez-Iturbe, I., Levin, S.A., 2012. Trading-off fish biodiversity, food security, and hydropower in the Mekong River Basin. Proceedings of the National Academy of Sciences 109, 5609-5614. doi:10.1073/pnas.1201423109 

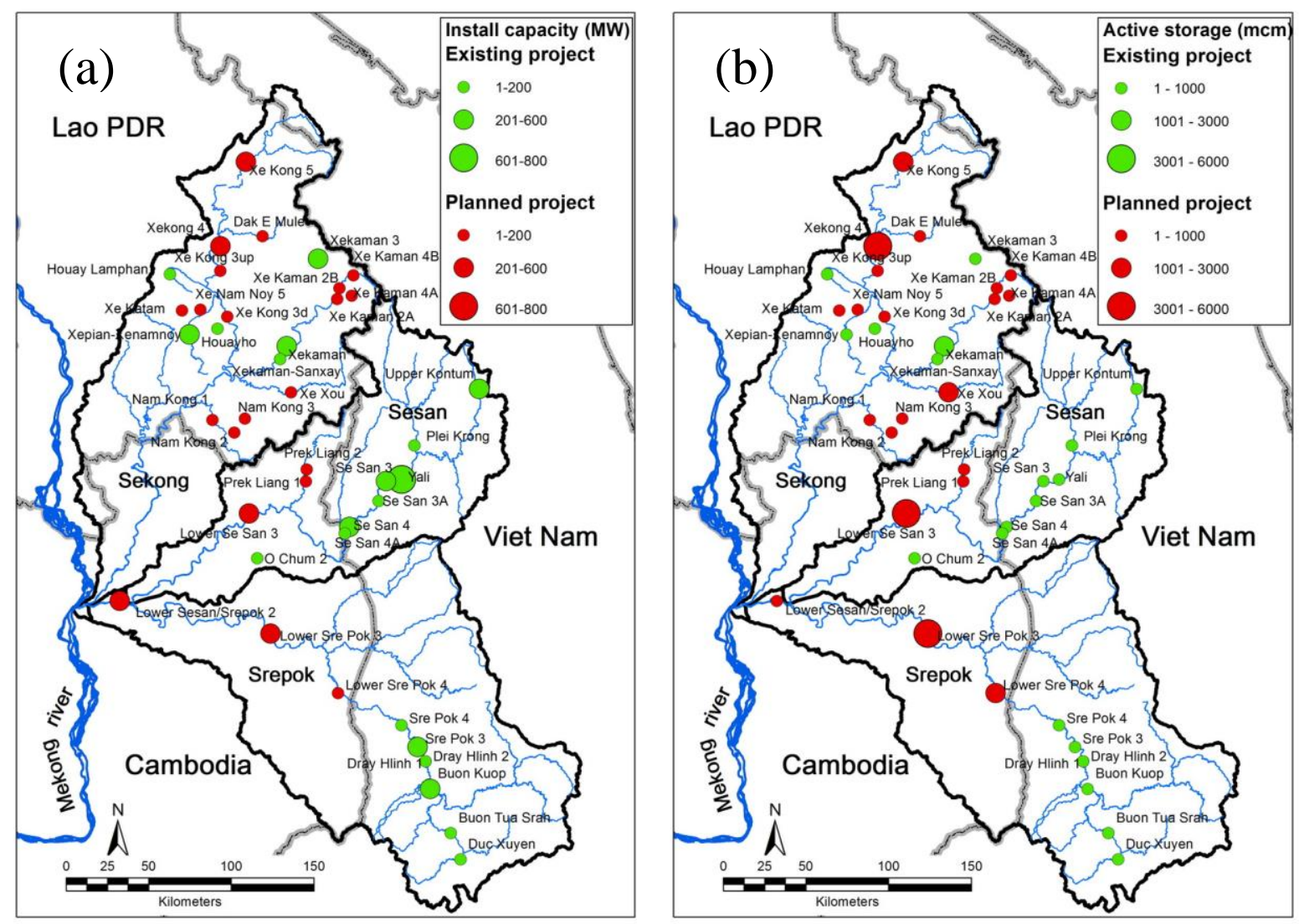

Figure 1. Hydropower development in the 3S Basin: a) installed capacity and b) active storage. 


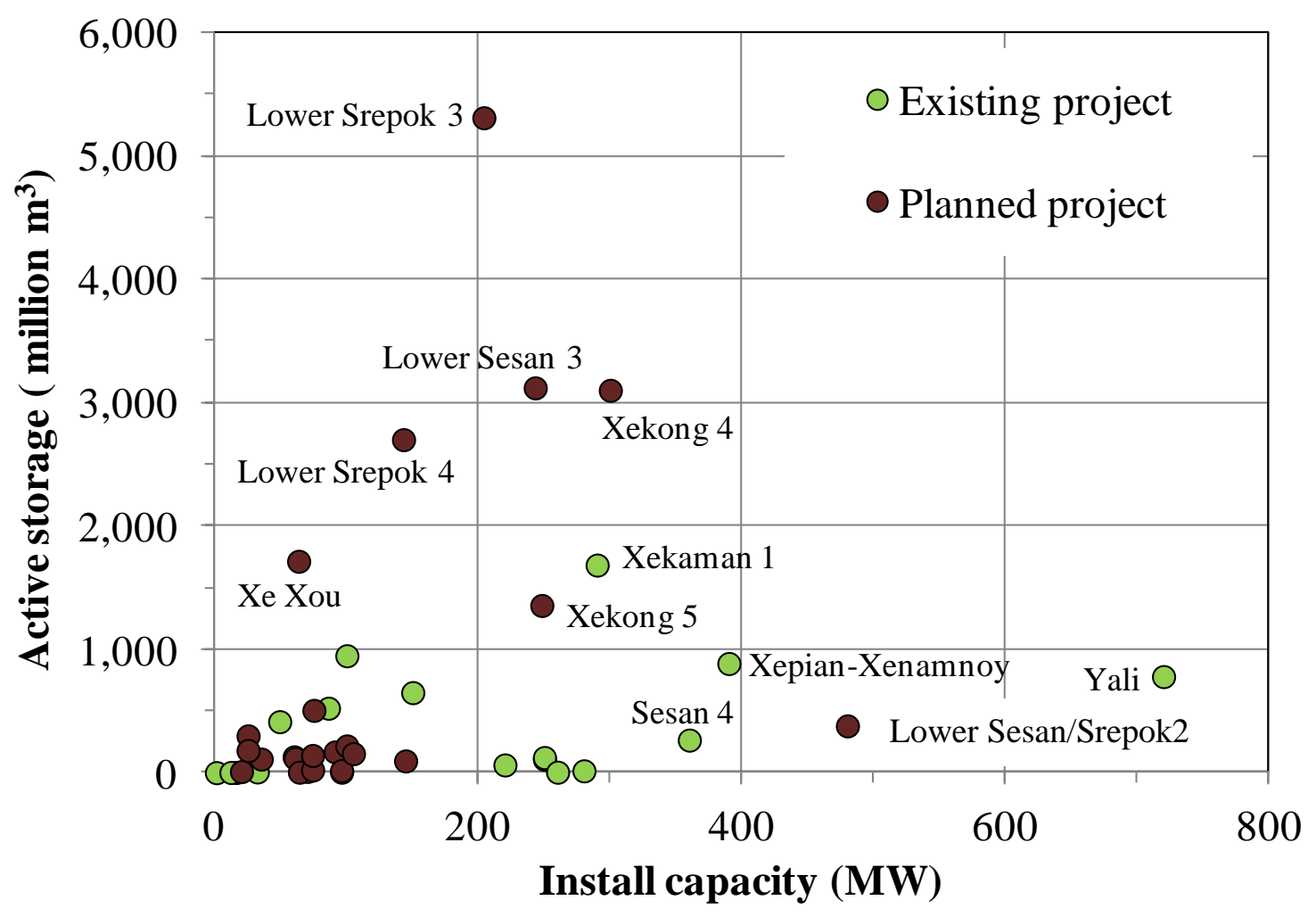

Figure 2. Comparison of the active storage and installed capacity of the hydropower projects in the $3 \mathrm{~S}$ Basin. 


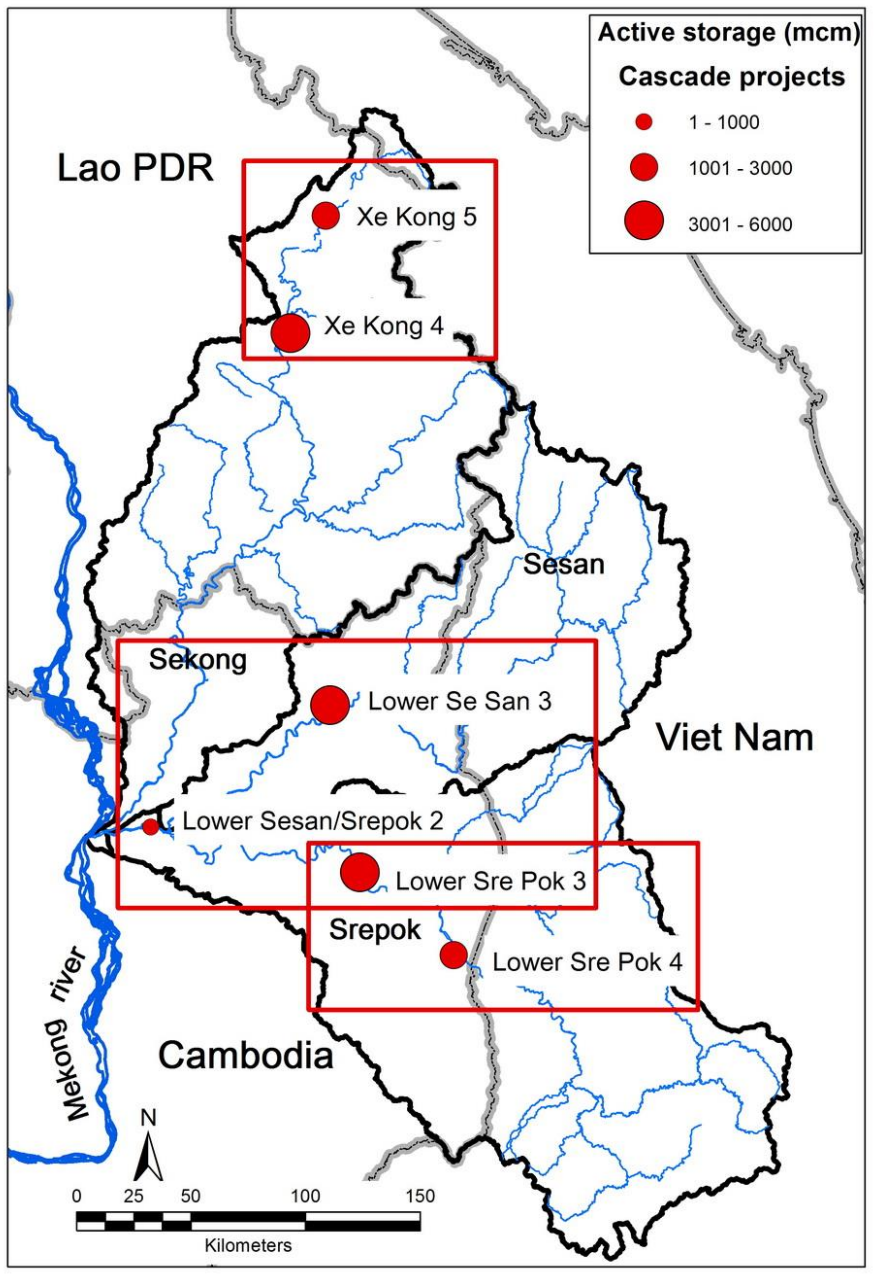

Figure 3. Active storage of individual dams within the three cascade dam systems studied. 


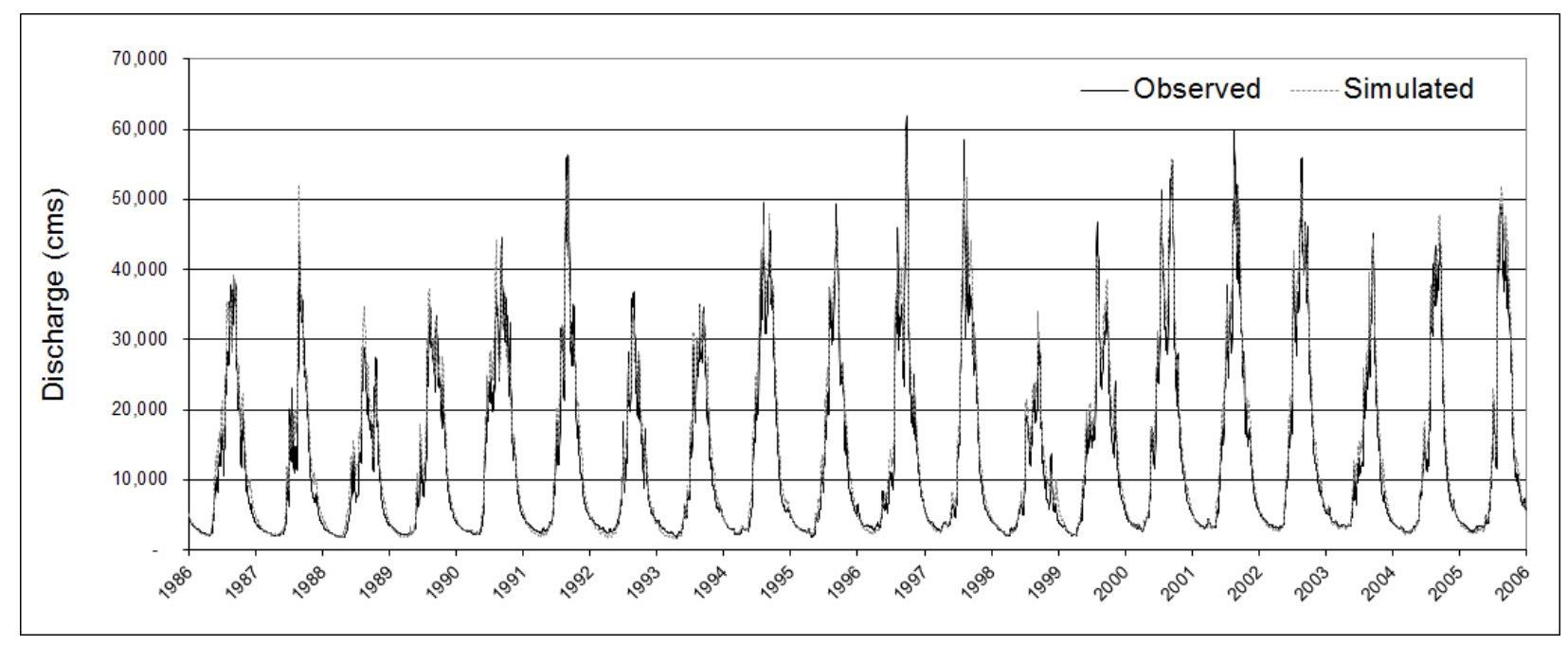

Figure 4. Comparison of observed and simulated discharge at Stung Treng station using the SWAT model during the 1986 to 2005 period. 


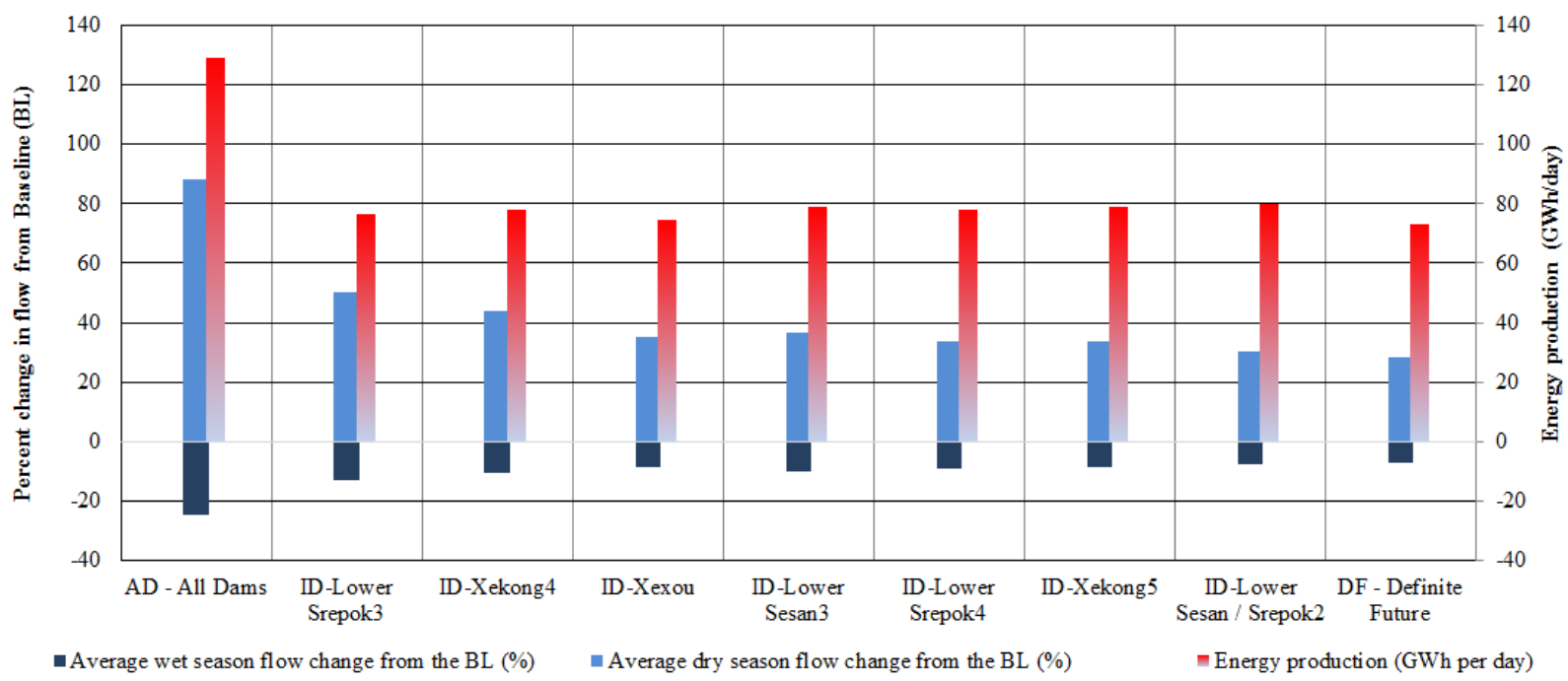

Figure 5. Comparison of percent changes in average wet and dry season flows from the Baseline (BL) at the 3S outlet and energy production for scenarios of All Dams (AD), the Definite Future (DF), and the DF scenario with Individual Dam (ID) scenarios. 


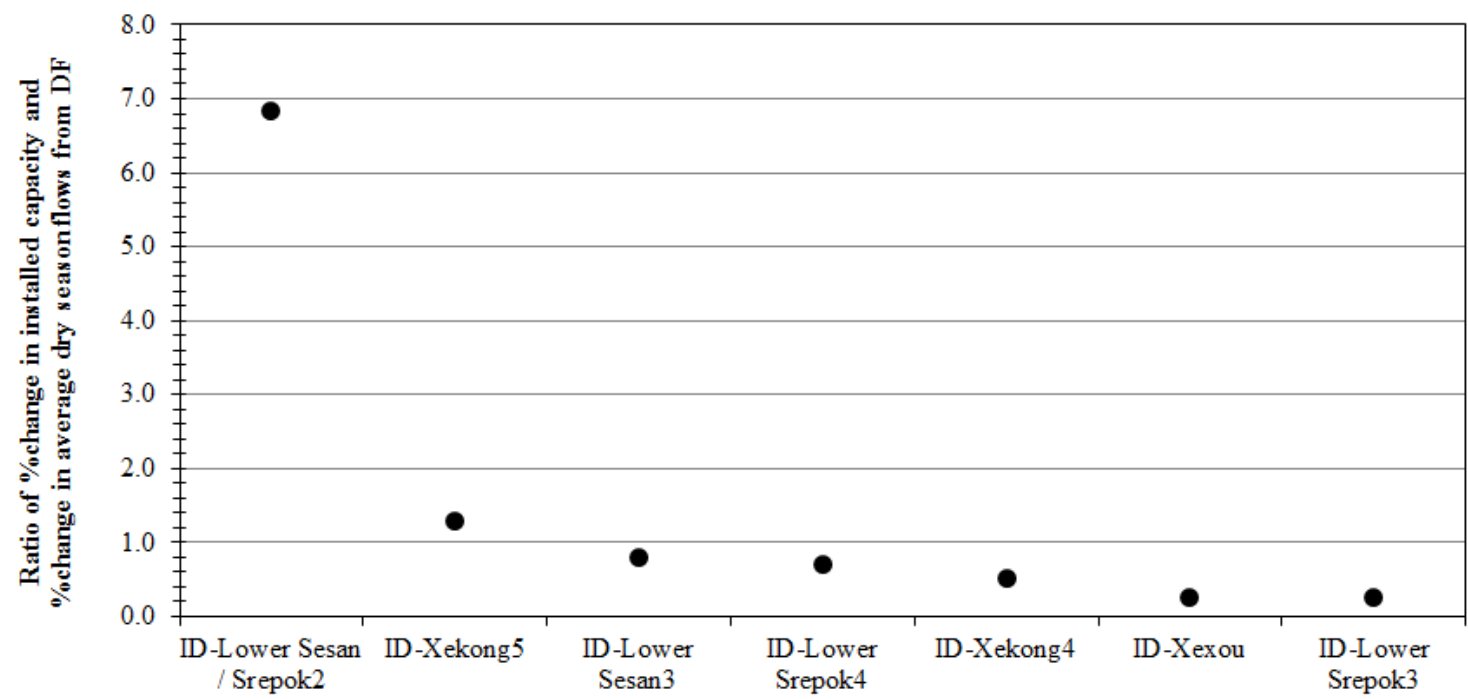

Figure 6. Ratio of percent change in installed capacity and percent change in average dry season flows of seven large dams from the Definite Future (DF) scenario. 

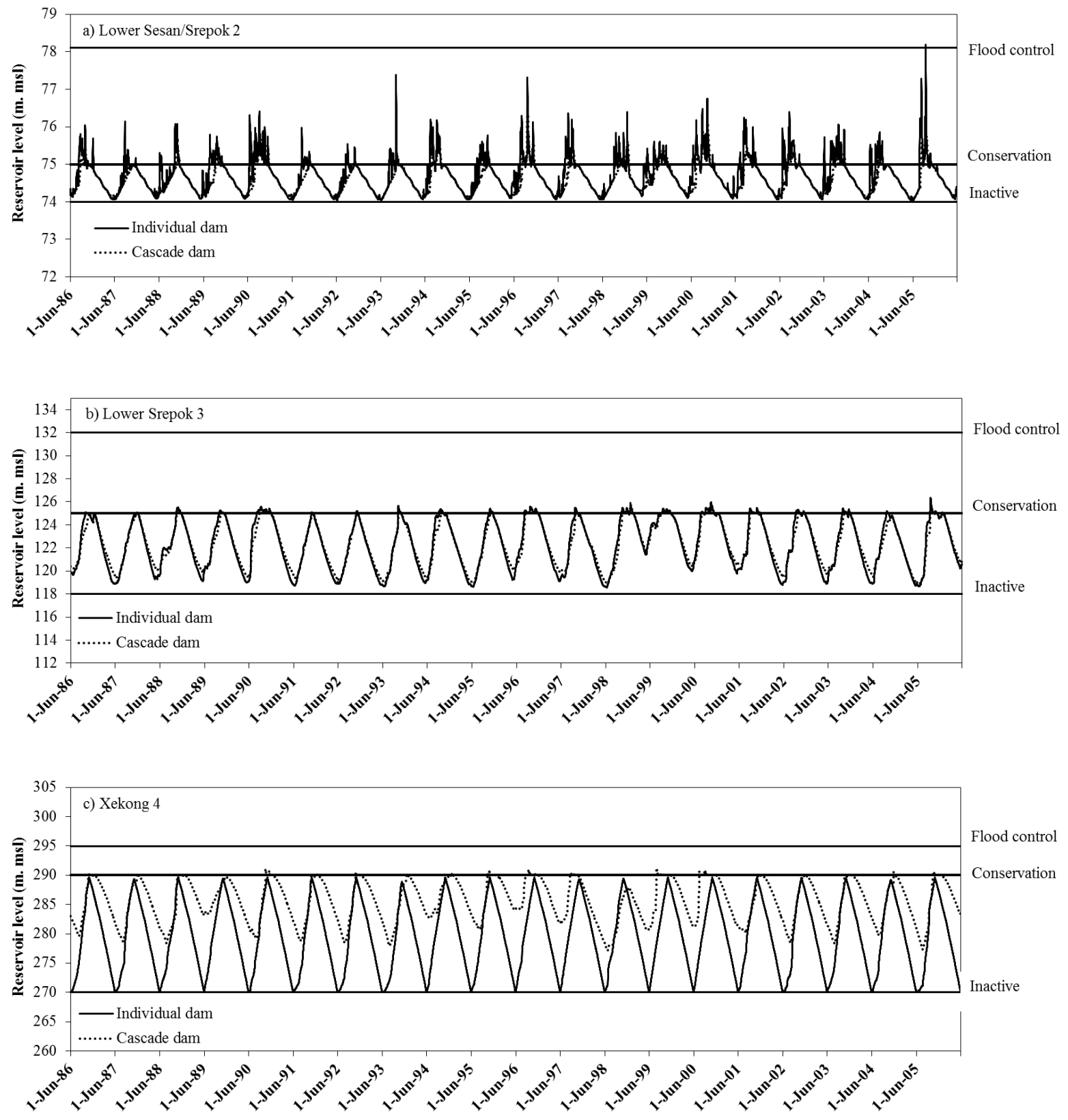

Figure 7. Comparison of reservoir levels under individual and cascade dam operations for the a) Lower Sesan/Srepok 2, b) Lower Srepok 3, and c) Xekong 4 dams. 


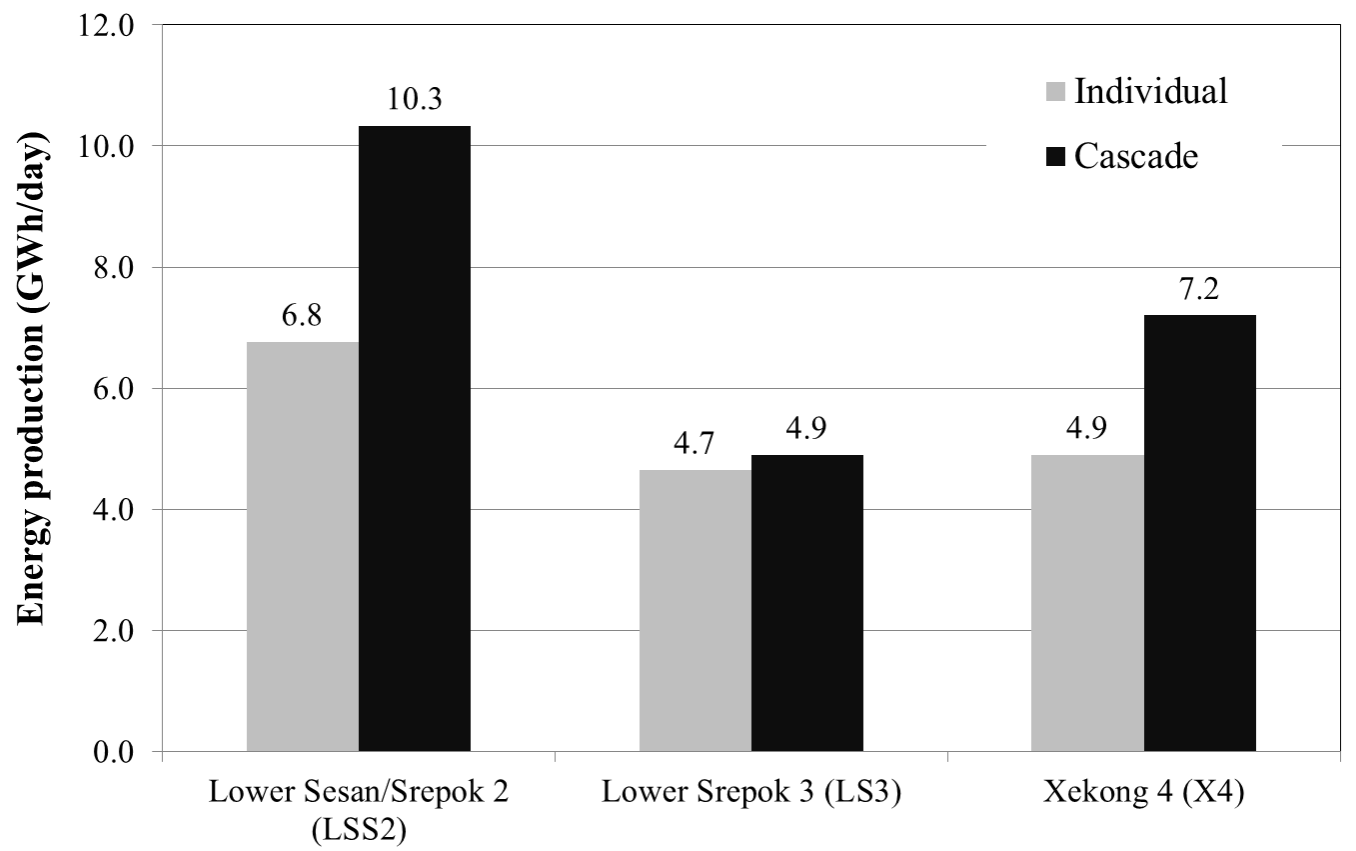

Figure 8. Comparison of energy production at the LSS2, LS3, and X4 dams from simulations without upstream dams operating (individual) and with upstream dams operating (cascade). 
Table 1. Hydropower characteristics and their inclusion in modeling scenarios. Data updated from MRC (2009).

\begin{tabular}{|c|c|c|c|c|c|c|c|c|c|c|c|}
\hline \multirow[t]{2}{*}{ No. } & \multirow[t]{2}{*}{ Name } & \multirow[t]{2}{*}{ Status } & \multirow{2}{*}{$\begin{array}{c}\text { Catchment } \\
\text { area } \\
\left(\mathbf{k m}^{2}\right)\end{array}$} & \multirow{2}{*}{$\begin{array}{c}\text { Full } \\
\text { supply } \\
\text { level } \\
\text { (m.msl) }\end{array}$} & \multirow{2}{*}{$\begin{array}{c}\text { Low } \\
\text { supply } \\
\text { level } \\
\text { (m.msl) }\end{array}$} & \multirow{2}{*}{$\begin{array}{c}\begin{array}{c}\text { Active } \\
\text { storage }\end{array} \\
\left(10^{6} \mathrm{~m} 3\right)\end{array}$} & \multirow{2}{*}{ 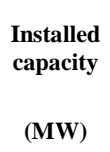 } & \multirow{2}{*}{$\begin{array}{l}\mathrm{S} / \mathrm{V} \\
(\%)\end{array}$} & \multicolumn{3}{|c|}{ Scenario } \\
\hline & & & & & & & & & DF & ID & AD \\
\hline & Lao PDR & & & & & & & & & & \\
\hline 1 & Houayho & E & 191.7 & 883.0 & 860.0 & 649.0 & 150.0 & 0.71 & $\mathrm{x}$ & $\mathrm{x}$ & $\mathrm{x}$ \\
\hline 2 & Xekaman 3 & UC & 712.0 & 960.0 & 925.0 & 108.5 & 250.0 & 0.12 & $\mathrm{x}$ & $\mathrm{x}$ & $\mathrm{x}$ \\
\hline 3 & Xekaman 1 & UC & $3,580.0$ & 230.0 & 218.0 & $1,683.0$ & 290.0 & 1.85 & $\mathrm{X}$ & $\mathrm{x}$ & $\mathrm{x}$ \\
\hline 4 & Xekaman-Sanxay & $\mathrm{UC}$ & $3,740.0$ & 123.0 & 122.0 & 7.1 & 32.0 & 0.01 & $\mathrm{x}$ & $\mathrm{x}$ & $\mathrm{X}$ \\
\hline 5 & Xepian-Xenamnoy & $\mathrm{UC}$ & 522.0 & 786.5 & 760.0 & 885.0 & 390.0 & 0.97 & $\mathrm{x}$ & $\mathrm{x}$ & $\mathrm{x}$ \\
\hline 6 & Houay Lamphan & $\mathrm{UC}$ & 140.0 & 840.0 & 800.0 & 128.2 & 60.0 & 0.14 & $\mathrm{x}$ & $\mathrm{x}$ & $\mathrm{x}$ \\
\hline 7 & Xe Kong 3up & $\mathrm{P}$ & $5,882.0$ & 160.0 & 155.0 & 95.1 & 144.6 & 0.10 & & & $\mathrm{x}$ \\
\hline 8 & Xe Kong 3d & $P$ & $9,700.0$ & 117.0 & 111.0 & 168.4 & 91.1 & 0.19 & & & $\mathrm{x}$ \\
\hline 9 & Xekong 4 & $P$ & $5,400.0$ & 290.0 & 270.0 & $3,100.0$ & 300.0 & 3.41 & & $\mathrm{x}$ & $\mathrm{x}$ \\
\hline 10 & Xe Kong 5 & $\mathrm{P}$ & $2,615.0$ & 500.0 & 470.0 & $1,355.5$ & 248.0 & 1.49 & & $\mathrm{x}$ & $\mathrm{x}$ \\
\hline 11 & Dak E Mule & $\mathrm{P}$ & 127.0 & 780.0 & 756.0 & 154.0 & 105.0 & 0.17 & & & $\mathrm{x}$ \\
\hline 12 & Xe Kaman 2A & $\mathrm{P}$ & $1,970.0$ & 280.0 & 275.0 & 3.7 & 64.0 & 0.004 & & & $\mathrm{x}$ \\
\hline 13 & Xe Kaman 2B & $\mathrm{P}$ & $1,740.0$ & 370.0 & 340.0 & 216.8 & 100.0 & 0.24 & & & $\mathrm{x}$ \\
\hline 14 & Xe Kaman 4A & $\mathrm{P}$ & 265.0 & 860.0 & 840.0 & 16.5 & 96.0 & 0.02 & & & $\mathrm{x}$ \\
\hline 15 & Xe Kaman 4B & $\mathrm{P}$ & 192.0 & 865.0 & 850.0 & 21.2 & 74.0 & 0.02 & & & $\mathrm{x}$ \\
\hline 16 & Xe Katam & $\mathrm{P}$ & 263.0 & 910.0 & 890.0 & 115.0 & 60.8 & 0.13 & & & $\mathrm{x}$ \\
\hline 17 & Xe Nam Noy 5 & $\mathrm{P}$ & 60.2 & 800.0 & 780.0 & 8.8 & 20.0 & 0.01 & & & $\mathrm{x}$ \\
\hline 18 & Xe Xou & $\mathrm{P}$ & $1,273.0$ & 180.0 & 160.0 & $1,714.0$ & 63.4 & 1.88 & & $\mathrm{x}$ & $\mathrm{x}$ \\
\hline 19 & Nam Kong 1 & $\mathrm{P}$ & $1,250.0$ & 320.0 & 287.0 & 505.0 & 75.0 & 0.55 & & & $\mathrm{x}$ \\
\hline 20 & Nam Kong 2 & $\mathrm{P}$ & 860.0 & 460.0 & 437.0 & 139.6 & 74.0 & 0.15 & & & $\mathrm{x}$ \\
\hline 21 & Nam Kong 3 & $\mathrm{P}$ & 650.0 & 540.0 & 520.0 & 298.6 & 25.0 & 0.33 & & & $\mathrm{x}$ \\
\hline & Cambodia & & & & & & & & & & \\
\hline 22 & O Chum 2 & $\mathrm{E}$ & 44.7 & 254.0 & 251.5 & 0.1 & 1.0 & 0.0001 & & & \\
\hline 23 & Lower Se San/Sre Pok 2 & $\mathrm{P}$ & $49,200.0$ & 75.0 & 74.0 & 379.4 & 480.0 & 0.42 & & $\mathrm{x}$ & $\mathrm{x}$ \\
\hline 24 & Lower Se San 3 & $P$ & $15,600.0$ & 150.0 & 147.0 & $3,120.0$ & 243.0 & 3.43 & & $\mathrm{x}$ & $\mathrm{x}$ \\
\hline 25 & Lower Sre Pok 3 & $\mathrm{P}$ & $26,200.0$ & 125.0 & 118.0 & $5,310.0$ & 204.0 & 5.84 & & $\mathrm{x}$ & $\mathrm{x}$ \\
\hline 26 & Lower Sre Pok 4 & $\mathrm{P}$ & $1,300.0$ & 190.0 & 185.0 & $2,700.0$ & 143.0 & 2.97 & & $\mathrm{x}$ & $\mathrm{X}$ \\
\hline 27 & Prek Liang 1 & $\mathrm{P}$ & 883.0 & 330.0 & 310.0 & 110.0 & 35.0 & 0.12 & & & $\mathrm{x}$ \\
\hline 28 & Prek Liang 2 & $\mathrm{P}$ & 595.0 & 515.0 & 496.0 & 180.0 & 25.0 & 0.20 & & & $\mathrm{x}$ \\
\hline & Viet Nam & & & & & & & & & & \\
\hline 29 & Plei Krong & $\mathrm{E}$ & $3,216.0$ & 570.0 & 537.0 & 948.0 & 100.0 & 1.04 & $\mathrm{x}$ & $\mathrm{x}$ & $\mathrm{x}$ \\
\hline 30 & Yali & $\mathrm{E}$ & $7,455.0$ & 515.0 & 490.0 & 779.0 & 720.0 & 0.86 & $\mathrm{x}$ & $\mathrm{x}$ & $\mathrm{X}$ \\
\hline 31 & Se San 3 & $\mathrm{E}$ & $7,788.0$ & 304.5 & 303.2 & 3.8 & 260.0 & 0.004 & $\mathrm{x}$ & $\mathrm{x}$ & $\mathrm{X}$ \\
\hline 32 & Se San 3A & E & $8,084.0$ & 239.0 & 238.5 & 4.0 & 96.0 & 0.004 & $\mathrm{x}$ & $\mathrm{x}$ & $\mathrm{x}$ \\
\hline 33 & Dray Hlinh 1 & E & $8,880.0$ & 302.0 & 299.0 & 1.5 & 12.0 & 0.002 & $\mathrm{x}$ & $\mathrm{x}$ & $\mathrm{X}$ \\
\hline 34 & Dray Hlinh 2 & $\mathrm{E}$ & $8,880.0$ & 302.0 & 299.0 & 1.5 & 16.0 & 0.002 & $\mathrm{x}$ & $\mathrm{x}$ & $\mathrm{X}$ \\
\hline 35 & $\operatorname{Se} \operatorname{San} 4 \mathrm{~A}$ & $\mathrm{E}$ & $9,368.0$ & 155.2 & 150.0 & 7.5 & & 0.01 & $\mathrm{x}$ & $\mathrm{x}$ & $\mathrm{x}$ \\
\hline
\end{tabular}




\begin{tabular}{|l|l|c|c|c|c|c|c|c|c|c|c|}
36 & Se San 4 & UC & $9,326.0$ & 215.0 & 210.0 & 264.2 & 360.0 & 0.29 & $\mathrm{X}$ & $\mathrm{X}$ & $\mathrm{X}$ \\
37 & Upper Kontum & UC & 350.0 & $1,170.0$ & $1,146.0$ & 122.7 & 250.0 & 0.13 & $\mathrm{X}$ & $\mathrm{X}$ & $\mathrm{X}$ \\
38 & Buon Tua Srah & UC & $2,930.0$ & 487.5 & 465.0 & 522.6 & 86.0 & 0.57 & $\mathrm{X}$ & $\mathrm{X}$ & $\mathrm{X}$ \\
39 & Buon Kuop & UC & $7,980.0$ & 412.0 & 409.0 & 14.7 & 280.0 & 0.02 & $\mathrm{X}$ & $\mathrm{X}$ & $\mathrm{X}$ \\
40 & Sre Pok 3 & UC & $9,410.0$ & 272.0 & 268.0 & 62.6 & 220.0 & 0.07 & $\mathrm{X}$ & $\mathrm{X}$ & $\mathrm{X}$ \\
41 & Sre Pok 4 & UC & $9,568.0$ & 207.0 & 204.0 & 10.1 & 70.0 & 0.01 & $\mathrm{X}$ & $\mathrm{X}$ & $\mathrm{X}$ \\
42 & Duc Xuyen & UC & $1,100.0$ & 560.0 & 551.0 & 413.4 & 49.0 & 0.45 & $\mathrm{X}$ & $\mathrm{X}$ & $\mathrm{X}$ \\
\hline
\end{tabular}

Note: $\mathrm{E}=$ Existing, $\mathrm{UC}=$ Under construction, $\mathrm{P}=$ Proposed, $\mathrm{BL}=$ Baseline, $\mathrm{DF}=$ Definite Future, $\mathrm{ID}=$ Individual Dam, $\mathrm{AD}=\mathrm{All}$ Dams $\mathrm{S} / \mathrm{V}=$ Ratio of active storage to mean annual flow volume at $3 \mathrm{~S}$ outlet 
Table 2.Comparison of changes in flow regimes at the $3 \mathrm{~S}$ outlet and energy production for the Baseline (BL), Definite Future (DF), and All Dams (AD) scenarios as well as for the DF scenario with Individual Dams (ID) scenarios.

\begin{tabular}{|c|c|c|c|c|c|c|c|c|c|c|c|c|c|c|}
\hline \multirow[t]{2}{*}{ Scenario } & \multicolumn{3}{|c|}{ Average wet season flow } & \multicolumn{3}{|c|}{ Average dry season flow } & \multicolumn{3}{|c|}{ Average maximum flow } & \multicolumn{3}{|c|}{ Average minimum flow } & \multicolumn{2}{|c|}{$\begin{array}{c}\text { Energy } \\
\text { production }\end{array}$} \\
\hline & $\mathrm{m}^{3} / \mathrm{s}$ & $\begin{array}{c}\% \\
\text { change } \\
\text { from } \\
\text { the BL }\end{array}$ & $\begin{array}{c}\% \\
\text { change } \\
\text { from } \\
\text { the DF }\end{array}$ & $\mathrm{m}^{3} / \mathrm{s}$ & $\begin{array}{c}\% \\
\text { change } \\
\text { from } \\
\text { the BL }\end{array}$ & $\begin{array}{c}\% \\
\text { change } \\
\text { from } \\
\text { the DF }\end{array}$ & $\mathrm{m}^{3} / \mathrm{s}$ & $\begin{array}{l}\text { \%chan } \\
\text { ge } \\
\text { from } \\
\text { the BL }\end{array}$ & $\begin{array}{l}\text { \%chan } \\
\text { ge } \\
\text { from } \\
\text { the DF }\end{array}$ & $\mathrm{m}^{3} / \mathrm{s}$ & $\begin{array}{l}\text { \%chan } \\
\text { ge } \\
\text { from } \\
\text { the BL }\end{array}$ & $\begin{array}{c}\% \\
\text { change } \\
\text { from } \\
\text { the DF }\end{array}$ & $\begin{array}{l}\text { GWh } \\
\text { per } \\
\text { day }\end{array}$ & $\begin{array}{l}\text { Chang } \\
\text { e from } \\
\text { the DF }\end{array}$ \\
\hline $\mathrm{BL}$ & 4,752 & & & 1,044 & & & 17,462 & & & 349 & & & - & \\
\hline DF & 4,421 & -7.0 & & 1,339 & 28.2 & & 15,098 & -13.5 & & 616 & 76.9 & & 73.2 & \\
\hline $\begin{array}{l}\text { ID-Lower Sesan / } \\
\text { Srepok2 }\end{array}$ & 4,393 & -7.5 & -0.6 & 1,359 & 30.2 & 1.9 & 12,699 & -27.3 & -13.7 & 640 & 83.7 & 6.8 & 80.0 & 6.8 \\
\hline ID-Lower Srepok3 & 4,140 & -12.9 & -5.9 & 1,569 & 50.3 & 22.1 & 12,710 & -27.2 & -13.7 & 760 & 117.9 & 41.1 & 76.6 & 3.4 \\
\hline ID-Lower Srepok4 & 4,330 & -8.9 & -1.9 & 1,395 & 33.7 & 5.5 & 14,215 & -18.6 & -5.1 & 727 & 108.6 & 31.8 & 77.8 & 4.7 \\
\hline ID-Lower Sesan3 & 4,275 & -10.0 & -3.1 & 1,424 & 36.4 & 8.2 & 13,900 & -20.4 & -6.9 & 764 & 119.1 & 42.2 & 79.0 & 5.8 \\
\hline ID-Xekong4 & 4,248 & -10.6 & -3.6 & 1,502 & 43.8 & 15.6 & 14,569 & -16.6 & -3.0 & 732 & 110.1 & 33.2 & 78.1 & 4.9 \\
\hline ID-Xekong5 & 4,350 & -8.4 & -1.5 & 1,393 & 33.5 & 5.2 & 14,500 & -17.0 & -3.4 & 672 & 92.9 & 16.0 & 79.1 & 6.0 \\
\hline ID-Xexou & 4,345 & -8.5 & -1.6 & 1,409 & 35.0 & 6.7 & 14,743 & -15.6 & -2.0 & 678 & 94.6 & 17.7 & 74.7 & 1.5 \\
\hline $\mathrm{AD}$ & 3,579 & -24.7 & -17.7 & 1,963 & 88.1 & 59.8 & 8,752 & -49.9 & -36.3 & 1,201 & 244.5 & 167.6 & 129.1 & 55.9 \\
\hline
\end{tabular}

